\title{
Field observations of the 17 July 2006 Tsunami in Java
}

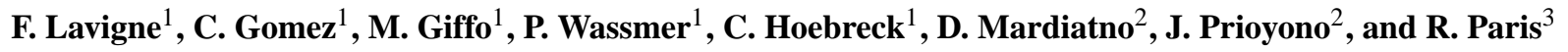 \\ ${ }^{1}$ Laboratoire de Géographie Physique, UMR CNRS 8591, Meudon, France \\ ${ }^{2}$ Research Center for Disasters, University Gadjah Mada, Indonesia \\ ${ }^{3}$ Géolab UMR 6042 CNRS, Clermont-Ferrand, France
}

Received: 9 October 2006 - Revised: 19 January 2007 - Accepted: 19 January 2007 - Published: 9 February 2007

\begin{abstract}
The 17 July 2006, a tsunami struck the southern coast of Java, Indonesia, causing over 730 casualties. The triggering earthquake located $225 \mathrm{~km}$ off the coast of Pangandaran $\left(9.222^{\circ} \mathrm{S}, 107.320^{\circ} \mathrm{E}\right)$, occurred at 15:19 LT (UTC +7) with a 7.7 magnitude on the Richter scale (Harward Center and CEA/DAM). In order to calibrate numerical models and understand the phenomenon, we conducted a 6-weeks field survey in July and August 2006 from Cimerak district in West Java to Gunung Kidul district in Central Java. Data collection involved measurements of wave height before its breaking, flow depth, run-up height, inundation depth, flow directions and a detailed chronology of the tsunami.

Eyewitnesses accounted for three main waves. The maximum height of the second wave ranged from 4.2 to $8.6 \mathrm{~m}$ before its breaking. Maximum flow depth after the wave's breaking reached $5 \mathrm{~m}$, and maximum runup heights reached $15.7 \mathrm{~m}$. Our run-up values are about 1.5 higher than those obtained by the other field surveys carried out until present. They are also higher than the values computed through preliminary models.

The 17 July 2006 tsunami has been generated by a "tsunami earthquake", i.e. an earthquake of low or medium scale that triggers a tsunami of high magnitude. The run-up heights progressively decreased eastwards, which is consistent with a tsunami triggered by fault dislocation, as the one that hit the Nicaragua's coast with similar run-up heights on the 2 September 1992. An earthquake with associated landslides could also have generated the 17 July 2006 tsunami, as ever observed in Papua-New-Guinea in 1998.
\end{abstract}

Correspondence to: F. Lavigne

(lavigne@univ-paris1.fr)

\section{Introduction}

A tsunami is an exceptional marine event characterised by high energy waves triggered by an earthquake, a volcanic eruption, or a submarine landslide (Fryer et al., 2003; Fine et al., 2004; Maramai et al., 2004; Tinti et al., 2005; Andrade et al., 2006). Around $75 \%$ of the Indonesian coastline is under threat from tsunamis. According to the NOAA (National Oceanic and Atmospheric Administration), during the last 450 years tsunamis have taken more than 470000 lives worldwide. The 26 December 2004 tsunami itself caused 230000 casualties, including 170000 in Indonesia.

The recent tsunami disaster struck the southern coast of Java on 17 July 2006 (Fig. 1a). At the beginning of August, the Indonesian Ministry of Health reported that approximately 668 people died, 65 were missing and 9299 were in-treatment as a result of the disaster (http://www.searo.who.int/LinkFiles/Indonesia -_Emergency_Situation_Report_ESR_11_3_Aug-06.pdf). At Pangandaran, the tsunami's intensity ranked 5 (very strong) on the Sieberg and Ambraseys' scale (Ambraseys, 1962), and between IX and X (destructive to very destructive) on the Papadopoulos and Imamura's scale (2001).

According to the USGS and the French CEA-DASE, this event was triggered by a 7.7 magnitude earthquake on the Richter scale that occurred at 8:19 GMT, 15:19LT. The epicentre $\left(9.222^{\circ} \mathrm{S}, 107.320^{\circ} \mathrm{E}\right)$ was located $34 \mathrm{~km}$ deep below the South of Pangandaran coastal resort (USGS).

This study aims at reconstructing the tsunami dynamics and phenomenology based on field measurements - wave and run-up heights, flow and inundation depth, flow directions - and testimonies along the coast over $230 \mathrm{~km}$ from Cimerak to Gunung Kidul (Fig. 1b). Data were collected by a French-Indonesian team during a period of 6 weeks field survey started on 18 July 2006 , one day after the event.

Published by Copernicus GmbH on behalf of the European Geosciences Union. 


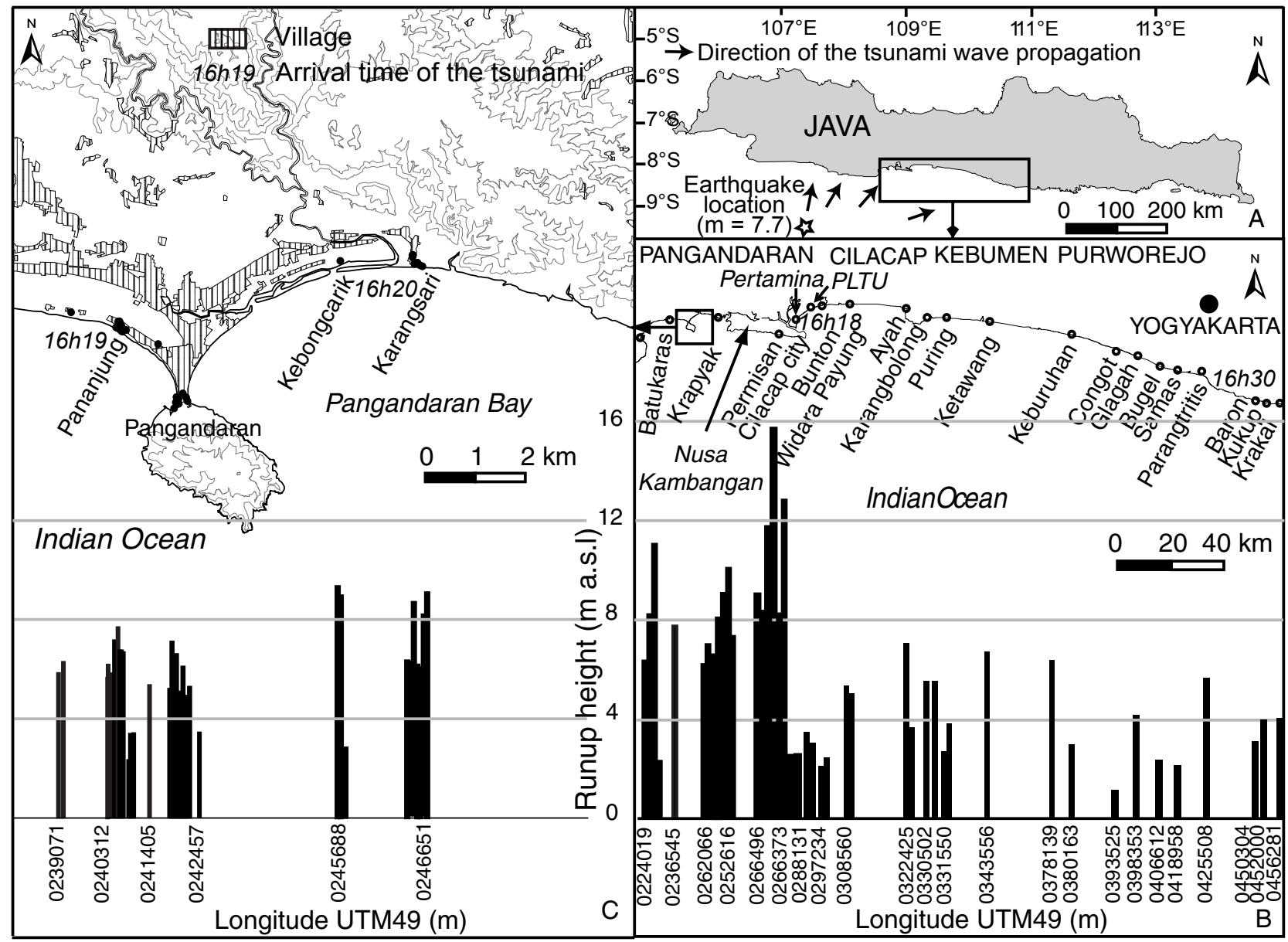

Fig. 1. Runup heights distribution of the 17 July 2006 tsunami along the south coast of Java. (A) Location of the field study in Java with indication of the 17 July 2004 earthquake epicentre. (B) Runup heights distribution and arrival time at selected spots along the Javanese coastline. (C) Zoom at the Pangandaran district.

\section{Methods}

We carried out 152 measurements of wave height before its breaking (i.e. height of the tsunami bore), run-up height and flow-depth distribution along the affected coastline (Supplement File: http://www.nat-hazards-earth-syst-sci.net/7/ 177/2007/nhess-7-177-2007-supplement.pdf). The run-up height is defined as the maximum vertical elevation of a point located on initially dry land that is inundated by the waves (Synolakis et al., 2005). The flow depth is measured from the ground. Using a laser range finder (LaserAce 300), we measured the highest marks on scorched trees - excluding palm trees and coconut trees that can bent - and the upper limit of destruction traces and mud lines on buildings and hill slopes. For these measures, the bench mark calculated from astronomical tide tables is the mean sea level. We also collected flow directions attested by tilted trunks, pillars, and debris using compass and GPS. In selected locations, we measured the inundation depth, defined as the maximum horizontal pene- tration of waves in the direction normal to the beach during the flooding (Synolakis et al., 2005).

On top of this data collection, we conducted interviews among local inhabitants in order to better understand the event's phenomenology. Questions included chronology, timing of the event, wave direction offshore, approximate values of the wave heights before their breaking and of the leading depression wave (i.e. the length of the sea recession). The tsunami breaking lines and other measured data were also confirmed through these interviews. The 17 July tsunami's witnesses are numerous and their testimonies are all in agreement. Furthermore, the surveys were carried out in the immediate aftermath of the disaster. Common problems of forgetfulness or the influence of unreliable eyewitnesses, influenced by an official version of the event were therefore reduced. 


\section{Results}

3.1 Wave and run-up height, tsunami intensity and overland flow depth

Along the south coast of Java between Batukaras and Baron (Fig. 1), the maximum height of the waves before their breaking ranged from 4.2 to $8.6 \mathrm{~m}$, and the measured runup heights (RU) ranged from less than $1 \mathrm{~m}$ to $15.7 \mathrm{~m}$ (Supplement File: http://www.nat-hazards-earth-syst-sci.net/7/ 177/2007/nhess-7-177-2007-supplement.pdf). The Fig. 1b clearly distinguishes two coastal regions based on the run-up heights of the tsunami: at Pangandaran district, wave heights as well as run-up heights commonly exceeded $8 \mathrm{~m}$, with an intensity of 2.5-3 on the Imamura and Ida's scale (Ida, 1956). East from Cilacap, the run-up values were lower than $6 \mathrm{~m}$ and the intensity less than 2.5 .

We measured the maximum run-up of the 1717 July 2006 tsunami on Nusa Kambangan Island. Near the prison of Permisan, a $5 \mathrm{~m}$ to $8 \mathrm{~m}$-high wave broke on the beach (Fig. 1b). Then the overland flow inundated tens or hundreds of meters, due to high cliffs and coastal hillslopes. The run-up values measured on these cliffs ranged from 8.2 to $15.7 \mathrm{~m}$ (Supplement File: http://www.nat-hazards-earth-syst-sci.net/7/177/ 2007/nhess-7-177-2007-supplement.pdf).

The highest run-up heights on the island of Java were measured at Batukaras (RU=10.4 m; Fig. 1b). In this area, the wave broke overland as far as $120 \mathrm{~m}$ from the shoreline, and the inundation depth reached hundreds of meters. At Keboncarik (Fig. 1c) and near Krapyak (RU=9.2 $\mathrm{m}$ at both sites), the wave broke on the beach and rapidly decreased landward as far as a few hundred meters, due to a raise in the local topography.

Other beaches were not so heavily affected by the tsunami waves. For example, the Pantai Timur (East Beach) of the Pangandaran peninsula (Fig. 1c) suffered from limited wave heights and inundation depth due to the urbanization of the Pantai Barat (West Beach). The high density of hotels along the seashore played the role of a barrier, so that the second range of hotel was not destroyed. The Pantai Timur was therefore only affected by refracted and diffracted waves. Five kilometres eastward, however, the local effects due to the peninsula are mitigated and the maximum run-up measured at Karangsari exceeded $8 \mathrm{~m}$ again.

In Cilacap city, run-up heights did not exceed $3 \mathrm{~m}$, barely reaching the beach ridge in front of the buildings of Pertamina. Indeed, the city was protected by the island of Nusa Kambangan. To the East of Cilacap, maximum run-up heights were measured at Pantai Ayah $(6.7 \mathrm{~m})$, where the tsunami wave broke on the wall along the beach. Then a progressive decrease of the run-up is observed along the coastline towards the East (Supplement File: http://www.nat-hazards-earth-syst-sci.net/7/177/ 2007/nhess-7-177-2007-supplement.pdf), until South of Yogyakarta city. Measured run-up in this area did not exceed
$4 \mathrm{~m}$, except in specific spots where the tsunami wave reached the top of the sand dunes up to $6.7 \mathrm{~m}$ a.s.l. (e.g. at Ketapang beach).

3.2 Tsunami arrival time, chronology, velocity, and flow directions

Along the Javanese coast, the chronological data collected show an eastward timing slide from Pangandaran to East Java and Bali. The tsunami event chronology is well known at Pangandaran (225 km away from the earthquake epicentre Fig. 1c), because a clock destroyed by the tsunami inside the hall of a school stopped working at 16:19 LT, one hour after the main earthquake. This is consistent with numerous reliable eyewitness accounts at Pangandaran and at Karangsari village a few kilometers east from Pangandaran peninsula. They attest to a wave arrival around 16:20 LT. At Keboncarik a violent wave entering the shrimp basins between 16:16 and 16:20 LT has been documented with photographs by two workers (Fig. 2). In Cilacap, images captured on videos at the PLTU power plant show the waves arrival at 16:18 LT in the water intake (Fig. 3), one hour after the earthquake, followed by a second wave of higher magnitude 2 to $3 \mathrm{~min}$ later. Then, a third one arrived on shores a few minutes later (Fig. 4). At Baron beach, about $200 \mathrm{~km}$ east of Pangandaran, fishermen were waiting for the high tide in front of a clock placed in a small "warung" (café) for this purpose, and could attest to the tsunami's arrival around 16:30 LT. In Bali, the tsunami wave was recorded by the tide gauge at Benoa beach at 17:00 LT, one hour and forty minutes after the earthquake.

The overall results on Javanese and Balinese coasts exemplify the progressive propagation of the wave from Pangandaran towards the East. The precise arrival time of the tsunami at several coastal locations allow us to calculate the tsunami mean velocity from the earthquake epicentre to Javanese and Balinese coasts. We computed the wave speed considering an earthquake point source, although an extended source may have triggered the tsunami. The tsunami reached Pangandaran and PLTU Cilacap in one hour with a mean velocity of 225 and $256 \mathrm{~km} / \mathrm{h}$, respectively. This velocity reached $300 \mathrm{~km} / \mathrm{h}$ until Baron Beach $-360 \mathrm{~km}$ away from the earthquake epicentre - and up to $510 \mathrm{~km} / \mathrm{h}$ until Benoa on Bali. These data highlight the increasing of the tsunami mean velocity towards the East. The wave propagation parallel to the isobaths explains the high velocity of the tsunami before it reached Bali. On the contrary, multiple refraction effects on the continental shelf near Pangandaran and Cilacap may explain the rapid decreasing of the tsunami velocity in these areas.

Three waves have been described and recorded almost everywhere. The first one was of little magnitude, a meter from the ground on average, and barely reaching the beach ridge. It was followed by the second wave, which was the highest one that we measured on the field. The tsunami wave orientation was most of 

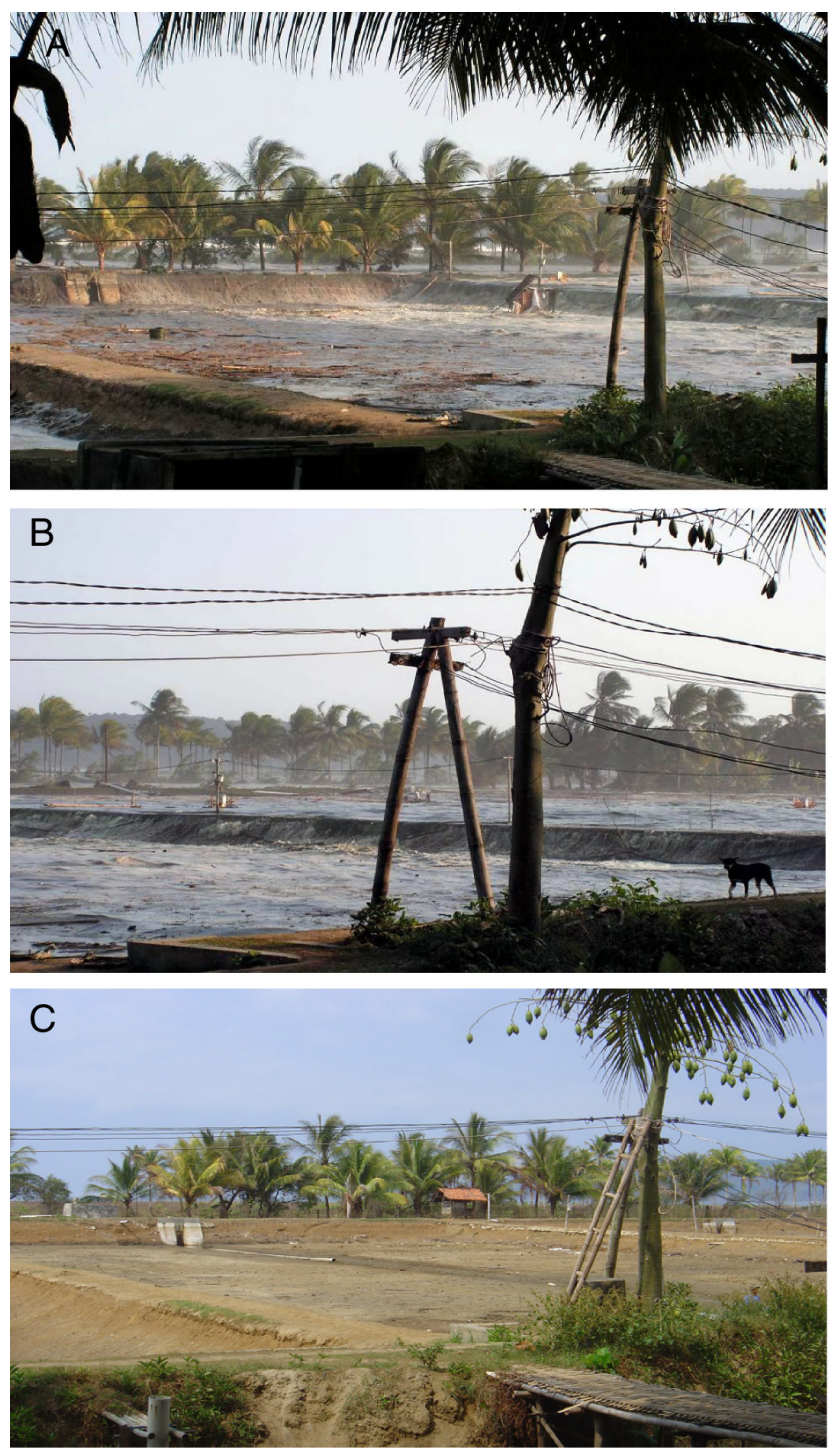

Fig. 2. Tsunami wave entering a shrimp basin (tambak) at Keboncarik between 16:16 and 16:20 (B, C). View of the same basin on the 30 August 2006. Photos: Pusat Studi Bencana (A, B) and F. Lavigne (C).

the time perpendicular to the coast, excepted for punctual variations due to local topographic settings (Supplement File: http://www.nat-hazards-earth-syst-sci.net/7/177/2007/ nhess-7-177-2007-supplement.pdf). On some beaches, a third wave has been reported by eyewitnesses. Its direction differed from the preceding one, suggesting that it was generated by reflection effects on the cliffs (e.g. at Keboncarik and Karangsari).

\section{Discussion and conclusion}

One and a half year after the megatsunami that destroyed the Aceh coastal regions, a new tsunami damaged the Javanese south coast on the 17 July 2006. This tsunami, which was triggered by a 7.7 earthquake located $220 \mathrm{~km}$ off Java Island, travelled the Indian Ocean with a velocity ranging from $225 \mathrm{~km} / \mathrm{h}$ - as far as West Java coast - to $510 \mathrm{~km} / \mathrm{h}$ as far as Bali. The tsunami propagation was faster than the one of the 2 September 1992 tsunami that hit the Nicaragua's coast $(180 \mathrm{~km} / \mathrm{h}$ : Kanamori and Masayuki, 1993). The epicenter of the 1992 earthquake was located at only $60 \mathrm{~km}$ from the coast. the velocity of the tsunami was therefore reduced by refraction effects. On the contrary, the velocity of the July 2006 tsunami wave was much lower than the one of the 26 December 2004 tsunami. On the same distance of $255 \mathrm{~km}$, the 2004 tsunami reached the coastline of Banda Aceh at $600 \mathrm{~km} / \mathrm{h}$ (Borrero, 2005), whereas the July 2006 reached Cilacap city at only $256 \mathrm{~km} / \mathrm{h}$, due to lesser ocean depth.

During the 17 July 2006 event, the drawdown related to the leading depression wave was followed by two main waves. A third wave reported by testimonies in several sites resulted from wave reflexion which should have enhanced the local effects of the tsunami, as reported on Babi Island on Flores in 1992 (Minoura et al., 1997).

The maximum wave height was $8.6 \mathrm{~m}$ and the maximum run-up height reached $15.7 \mathrm{~m}$ a.s.l. Our results highlight three main issues.

Firstly, our results are not consistent with the different results presented until now on the internet by most of the other survey teams. Indeed, the other teams have underestimated the maximum run-up heights. For example, the team conducted by Widjo Kongko (BPPT) measured a maximum runup height reaching only $3.6 \mathrm{~m}$ a.s.l (http://ioc3.unesco.org/ itic/files/tsunami-java170706_e.pdf). As for the team of the Indonesian Geological Survey, they measured a $3.3 \mathrm{~m}$ maximum in Pangandaran (http://www.grdc.esdm.go.id), which is less than half the values we measured. The closest values to ours were found by the team led by Prof. Tsuji, which reported run-up heights that are close to the one we have measured, e.g. $7.7 \mathrm{~m}$ at Pangandaran (http://aeic.bmg.go.id/file/ Pangadaran_report_en.pdf).

These discrepencies may be explained by two factors. On a first hand it is necessary to do a quick field survey before the tsunamis' marks are erased, but several weeks of field surveys are needed to get accurate data. It is necessary to conduct a long and cautious survey in order to collect the maximum data, since it can vary spatially. Indeed local topographical effects - e.g. wave traps - are numerous and greatly influence the results. On the other hand, the other field survey teams focused on flow depth measurements and did not take into account the tsunami height before the breaking of the highest wave -i.e. the tsunami bore - on the beach or further inland. Yet, we observed great variations between both types of data, which varied by as much as twice within a few meters on Ayah Beach. The highest wave broke on the protection dyke scorching a few trees at more than $6 \mathrm{~m}$ a.s.l. At the back, all the other trees were scorched at less than 

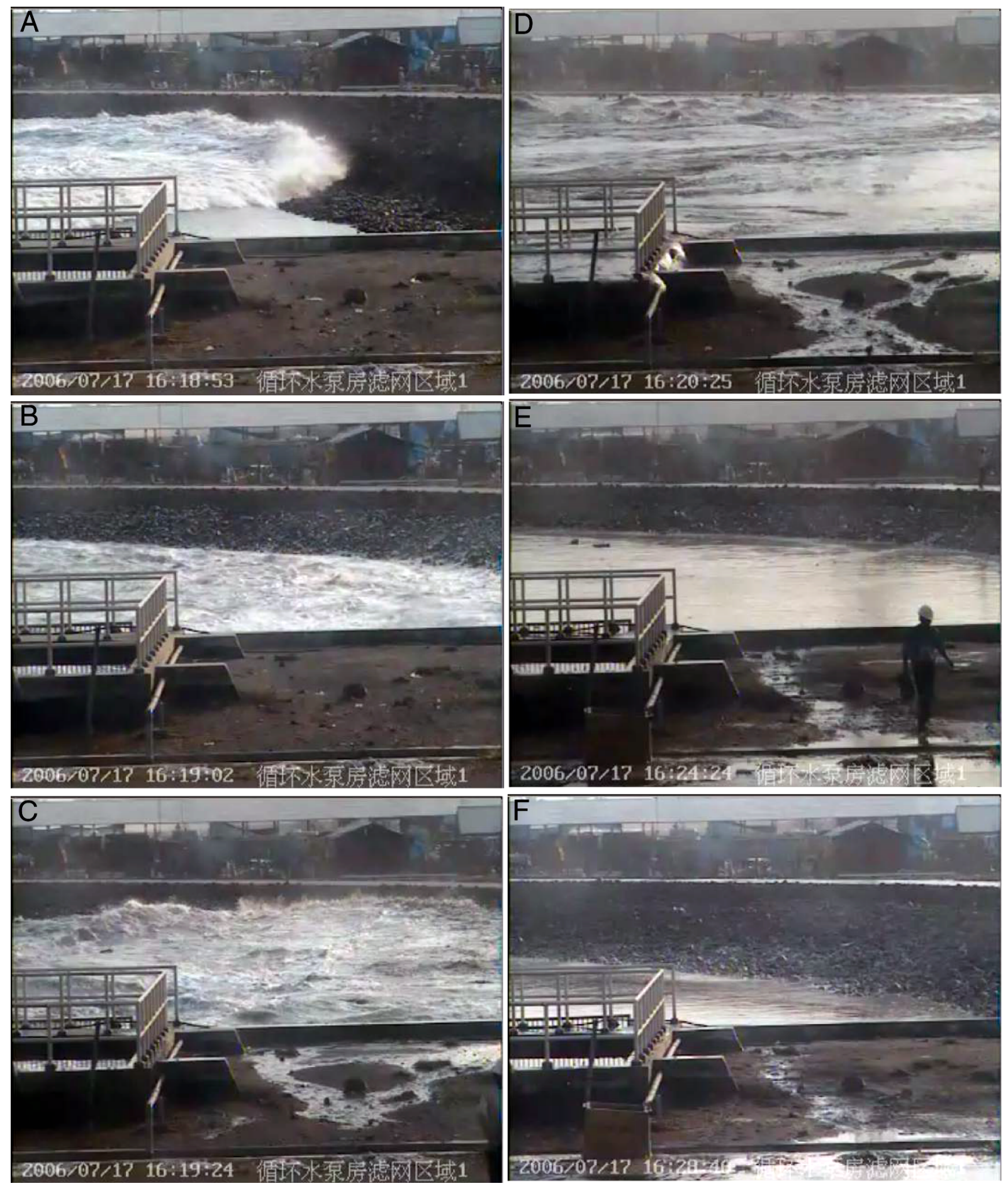

Fig. 3. Tsunami waves at the PLTU power plant. (A) Tsunami bore of the first wave at 16:18:53 LT. (B) Drawdown following the first wave at 16:19:02 LT. (C) Second wave at 16:19:24 LT. (D) Maximum flow depth at 16:20:25 LT. See some PLTU staff carried by the tsunami wave. (E) Drawdown at 16:24:24 LT. (F) Normal sea level at 16:28:40 LT. Courtesy: Ir. Chandra Dwi Putra, MM, PLTU Cilacap.

$3.5 \mathrm{~m}$. This breaking line has been confirmed by eyewitness accounts.

Secondly, this tsunami was without any doubt bigger than predicted by theoretical models. Indeed, the measured run- up heights are not consistent with the one predicted by theoretical models presented on the ITIC-UNESCO website (International Tsunami Information Center: http://ioc3. unesco.org/itic/). Indeed, the preliminary models run at 


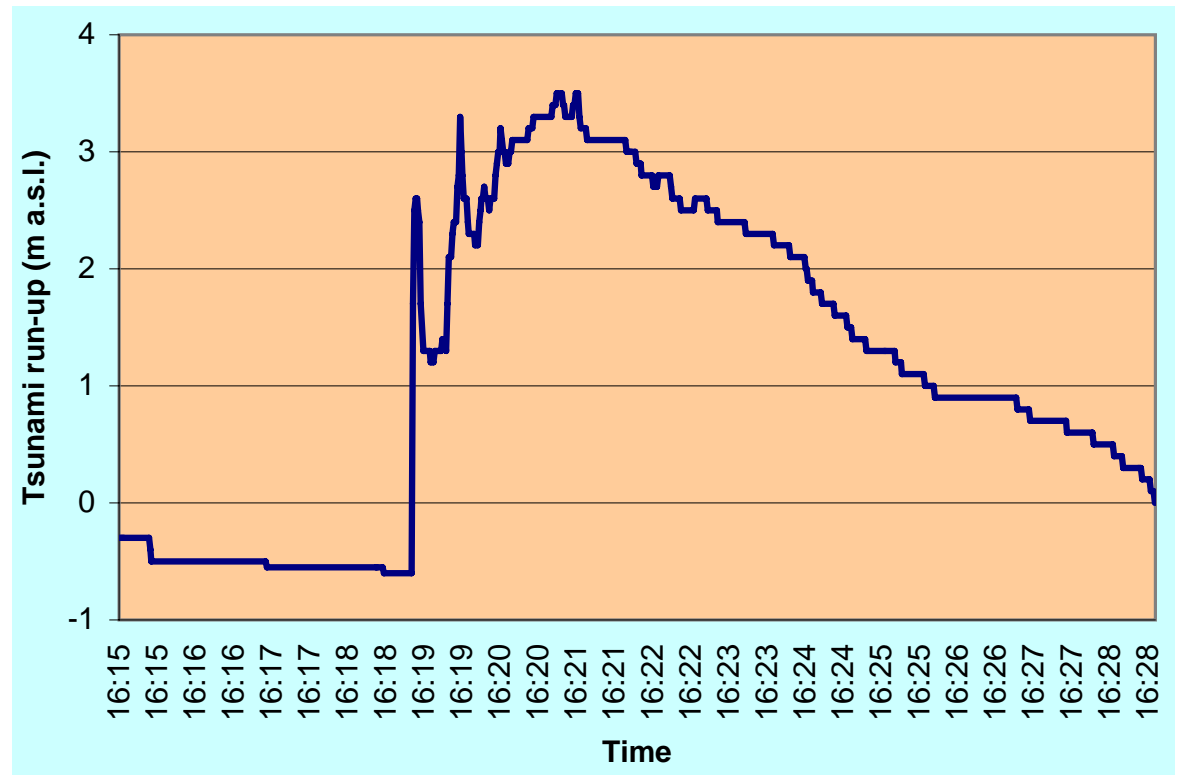

Fig. 4. Hydrogram of the tsunami at the PLTU power plant. We have reconstructed the tsunami depth through video frame analysis.

Tohoku University (http://www.tsunami.civil.tohoku.ac.jp/ hokusai2/disaster/06_Java/July17_Java.html), Bologna University (http://labtinti4.df.unibo.it/site/simulation_java.php), or CEA (http://www-dase.cea.fr/actu/dossiers_scientifiques/ 2006-07-17/index.html) give maximum run-up values ranging from $0.1 \mathrm{~m}$ to $3.5 \mathrm{~m}$. These values are a quarter to a half of those we measured on the Javanese coast. These differences may result from two main reasons. Firstly, the different models have not been calibrated with field data as yet, and were only based on the tsunamigenic earthquake properties and rough bathymetric settings. Secondly the 17 July 2006 tsunami may have been generated by a tsunami earthquake, i.e. an earthquake of low or medium scale that trigger a tsunami of high magnitude. Run-up higher than predicted on the basis of the magnitude of the tsunamigenic earthquake may result from the creation of a new fault associated with subducted sediments along the Java trench. In this case, the origin of this tsunami should be compared to the 2 September 1992 tsunami earthquake of magnitude 7 that hit the Nicaragua's coast with similar run-up heights ranging from 8 to $15 \mathrm{~m}$ (Kanamori and Masayuki, 1993). An earthquake with associated landslides could also have generated the 17 July 2006 tsunami. Indeed, similar events have already been reported in 1771 and 1896 on the Japanese Islands of Ryukyu and Honshu (NGDC database), or in 1946 in the Aleutian archipelago (Fryer et al., 2003). The 1998 tsunami earthquake on Papua New-Guinea generated run-up heights up to $15 \mathrm{~m}$ (Tappin et al., 2001), which is comparable to the maximum run-up heights we measured in 2006 along the Javanese coast.

Thirdly, if we compare the 2006 event with the 2004 tsunami at Banda Aceh, we can observe differences but also similarities. The 17 July 2006 tsunami was triggered by a 7.7 magnitude earthquake on the Richter scale, which is not as important as the 9.3 tsunamigenic earthquake triggered on the 24 December 2004 (Stein et al., 2005). Therefore run-up heights were not as elevated as the $51 \mathrm{~m}$ run-up measured to the South of Lhok Nga at Labuhan (Lavigne et al., 2006a, b), but still presented a maximum run-up in excess of $15 \mathrm{~m}$ a.s.l. Moreover the continental shelf to the South of Java Island is not as wide as the one extending away from Aceh, and therefore not prone to gigantic run-up heights. The event was of smaller magnitude, which explains the limited geomorphologic impacts. The 17 July 2004 tsunami did not generate significant flooding lasting from months to years as in Banda Aceh (Wassmer et al., 2006), nor could it decapitate sand dunes like in Lampuuk (Gomez et al., 2006). Regarding the tsunami impacts on the infrastructures, the seaside villages of the south coast of Java were not totally destroyed. Only the single storey houses and the hotel's ground floors were heavily damaged.

However there were similarities between both events. Indeed, the waves' train was of a similar pattern for the 17 July 2006 and the 26 December 2004 tsunamis. The first wave barely reached $1 \mathrm{~m}$ a.s.l. for both events, and was followed by a second wave which was in both cases the biggest. Then a third wave immediately followed the second one in both cases. At Banda Aceh, the first wave has been interpreted as being the foot of the main one (Lavigne et al., 2006) and the same phenomenon seemed to have occurred on the Javanese coast since no retreat was observed between the first and the second wave. This pattern has also been observed in Sri Lanka (Yamada et al., 2006). 
Although of lesser magnitude than the dramatic 2004 event, the 2006 tsunami in Java took more than 800 lives. It was much more deadly and destructive than the last tsunamirelated disaster that occurred on East Java in 1994 (Maramai and Tinti, 1997; Tsuji et al., 1995). In fact, the 2006 event is the most deadly earthquake-triggered tsunami ever recorded for this island.

Acknowledgements. The authors are indebted to the French Délégation Interministérielle pour l'Aide Post-Tsunami (DIPT), the French Embassy in Indonesia, and the French CNRS (ATIP program) for financial support. We are also grateful for the cooperation and help extended to us by the Research Center for Risk at Gadjah Mada University. H. Hébert and F. Schindele (CEA) are acknowledged for their advice.

Edited by: S. Tinti

Reviewed by: two referees

\section{References}

Ambraseys, N. N.: Data for the investigation of the seismic seawaves in the Eastern Mediterranean, Bulletin of the Seismological Society of America, 52, 895-913, 1962.

Andrade, C., Borges, P., and Freitas, M. C.: Historical tsunami in the Azores archipelago (Portugal), Journal of Volcanology and Geothermal Research, 156, 1-2, 172-185, 2006.

Borrero, J. C: Field data and satellite imagery of the tsunami effects in Banda Aceh, Science, 308, 1596, 2005.

Fine, I. V., Rabinovich, A. B., Bornhold, B. D., Thomson, R. E., and Kulikov, E. A.: The Grand Banks landslide-generated tsunami of November 18, 1929: preliminary analysis and numerical modelling, Marine Geology, 215, 1-2, 45-57, 2004.

Fryer, G. J., Watts, P., and Lincoln, F.: Source of the great tsunami of 1 April 1946: Aleutian forearc, Mar. Geol., 203, 1-2, 201218, 2003.

Gomez, C., Lavigne, F., Lespinasse, N., Saintenoy, A., and Leparoux, D.: Mise en évidence de dunes tronquées par le tsunami du 26 décembre 2004 et de dépôts sableux corrélatifs par radar géologique, in: Le tsunami du 26 décembre 2004 en Indonésie. Rapport scientifique du programme TSUNARISQUE. Délégation Interministérielle pour l'aide Post-Tsunami (DIPT), edited by: Lavigne, F. and Paris, R., 127-134, 2006.

Ida, K.: Earthquakes accompanied by tsunamis occurring under the sea off the islands of Japan, J. Earth Sci., Nagoya University, 4, $1-43,1956$.

Kanamori, H. and Masayuki, K.: The 1992 Nicaragua earthquake: a slow tsunami earthquake associated with subducted sediments, Nature, 361, 714-716, 1993.

Lavigne, F., Paris, R., Wassmer, P., Gomez, C., Brunstein, D., Grancher, D., Vautier, F., Sartohadi, J., Setiawan, A., Syahnan, Gunawan, T., Fachrizal, Waluyo, B., Mardiatno, D., Widagdo, A., Cahyadi, R., Lespinasse, N., and Mahieu, L.: Learning from a major disaster (Banda Aceh, December 26th, 2004): a methodology to calibrate simulation codes for tsunami inundation models, Zeitschrift für Geomorphologie, N.F., Suppl.-vol. 146, 253265, 2006a.
Lavigne, F., Paris, R., Grancher, D., Wassmer, P., Setiawan, A., Syahnan, Gunawan, T., Fachrizal, Waluyo, Cahyadi, R., Flohic, F., De Coster, B., and Mahieu, L.: Le tsunami du 26 décembre 2004 : chronologie et reconstitution de la catastrophe dans la région de Banda Aceh Sumatra, Indonésie, in: Le tsunami du 26 décembre 2004 en Indonésie, Rapport scientifique du programme TSUNARISQUE. Délégation Interministérielle pour l'aide PostTsunami (DIPT), edited by: Lavigne, F. and Paris, R., 21-37, 2006b.

Maramai, A., Graziani, L., and Tinti, S.: Tsunamis in the Aeolian Island (southern Italy): a review, Mar. Geol., 215, 1-2, 11-21, 2004.

Maramai, S. and Tinti S.: The 3rd June, 1994 Java tsunami: a post-event survey of the coastal effects, Nat. Hazards, 15, 3149, 1997.

Minoura, K., Imamura, F., Takahashi, T., and Shuto, N: Sequence of sedimentation processes caused by the 1992 Flores tsunami: Evidence from Babi Island, Geology, 25, 6, 523-526, 1997.

Papadopoulos, G. A. and Imamura, F.: A proposal for a new tsunami intensity scale, Proc. Internat. Tsunami Conference, 7-9 August 2001, Seattle, 569-577, 2001.

Stein, S. and Okal, E.: Speed and size of the Sumatra earthquake, Nature, 434, 581-582, 2005.

Synolakis, C., Okal, E., and Bernard, E.: The Megatsunami of December 26 2004, Bridge, 35, 2, 26-35, 2005.

Tappin, D. R., Watts, P., McMurtry, G. M., Lafoy, Y., and Matsumoto, T.: The Sissano, Papua New Guinea Tsunami of July 1998 - Offshore Evidence on the Source Mechanism, Mar. Geol., 175, 1-23, 2001.

Tinti, S., Armigliato, A., Manucci, A., Pagnoni, G., Zaniboni, F., Yalciner, A. C., and Altinok, Y.: The generating mechanisms of the August 17, 1999 Izmit bay tsunami: Regional tectonic and local mass instabilities causes, Mar. Geol., 225, 1-4, 311-330, 2005.

Tsuji, Y., Imamura, F., Matsutomi, H., Synolakis, C. E., Nanang P. T., Jumadi, Harada, S., Han, S. S., Arai, K., and Cook, B.: Field Survey of the East Java Earthquake and Tsunami of June 3, 1994, Pure Appl. Geophys., 144, 3/4, 839-854, 1995.

Wassmer, P., Paris, R., and Lavigne, F.: Apports de la photographie aérienne oblique dans l'analyse des impacts environnementaux du tsunami, in: Le tsunami du 26 décembre 2004 en Indonésie, Rapport scientifique du programme TSUNARISQUE. Délégation Interministérielle pour l'aide Post-Tsunami (DIPT), edited by: Lavigne, F. and Paris, R., 97-113, 2006.

Yamada, S., Gunatilake, R. P., Roytman, T. M., Gunatilake, S., Thushara, F., and Lalan, F.: The Sri Lanka Tsunami Experience, Disaster Damage Response, 4, 38-48, 2006. 